\title{
Outsourcing of R\&D Activities to Brazilian Subsidiaries
}

\author{
Dusan Schreiber \\ Faculdade IENH \\ dusan.s@ienh.com.br \\ Ivan Antônio Pinheiro \\ Universidade Federal do Rio Grande do Sul - UFRGS \\ iapinheiro@ea.ufrgs.br
}

\begin{abstract}
The decision-making process that results in carrying out R\&D activities in the internal, non-internal or combined way involves a series of variables and deserves a more detailed analysis due to its specificities. This need stems from the relevance of R\&D activities in the organizational universe, verified more in the last decades, due to the possibility for the formation of the competitive edge. The R\&D area represents the organizational unit responsible for converting the body of knowledge that permeates the fabric of the organization into innovation of products and processes aiming to achieve the sustainability of the organization. The change in the profile of the $R \& D$ area in recent years, allowed to observe repositioning of this highly technical area, through converting it into a more integrated unit in the organizational world, by more intense interaction with other organizational units, filtering information used in the innovation process. Following the logic of rationality in the theory of transaction costs, evidenced by the dilemma "make or buy?", the R\&D activities are analyzed in the possibility to be carried out internally or externally. In many cases outsourcing may occur even across national borders. This paper was created with the aim of examining the case of three multinational companies that have outsourced their R\&D activities to Brazil based on a strategic perspective, in order to understand the contextual framework that led to different configurations of the R\&D activity in these three subsidiaries, providing new possibilities of design for international management of operations. The results highlight the importance of relations of trust, based on local expertise, regardless of pre-existing or developed, as background for the decision of multinational firms in order to transfer more complex activities such as research and development to the subsidiaries in Brazil. The authors hope to contribute to the debate on the advantages and benefits of the process of the outsourcing of these activities.
\end{abstract}

\section{INTRODUCTION}

The expansion of business operations to other countries is not exactly a new fact and neither an innovation. What, however, may be considered innovative, is the systematization of knowledge that is the basis of the set of decisions that guides the choice of how to internationalize the operations and organization of such operations as a whole.

With guaranteed presence in the domestic market and consolidation of the initial stage of internation- alization through exports, firms realized that they needed to establish themselves in the countries of their exports destination. The most relevant options for direct investment abroad are: (i) build an own manufacturing plant, (ii) acquire a local company with its own brand and consolidated network of customers, suppliers and partners, and (iii) associate to a local business through a joint venture contract. Each of these alternatives denote advantages and disadvantages, besides resulting in different strategies of action for each of the organizational 
units and type of relationships between head office and subsidiary, different forms of knowledge management, capitalization, sharing resources and management autonomy. The asymmetry of the information available upon foreign markets highlights the importance of the "make or buy" option, depending on cost and characteristics of human and material resources and on the range of risks involved in the operation of foreign direct investment, such as political and technological risks.

However, in the last two decades, it is possible to verify the emergence of a new focus in the process of the internationalization that aims to outsource research and development activities, regarded hitherto as central to organizational operation. Despite increased focus on sectors like software development and pharmaceuticals, this trend has also been found in other sectors, such as metal-mechanical, chemical, polymer, paper and cellulose. The decision of outsourcing R\&D activities could be considered, at first glance, as going against good management practice and theory, but it has a solid and consistent theoretical background in strategy, operational theory, technology management, and marketing, in addition to the economical and rational approach.

The advantages of cost or differentiation, in addition to the formation of cartel among the organizations of the same economic sector, was tied to a number of other variables, such as the competitive advantage based on technology and knowledge, with the methods of knowledge management incorporated to the management practices aiming at designing strategic actions, not only in local but also in global markets. Operating with maximum efficiency has become the central focus of organizations, forcing companies to compete on the basis of specific characteristics and distinctive capabilities.

Initially, the outsourcing of R\&D activities followed the same process of international expansion, in terms of direct investment - FDI (Foreign Direct Investment), operating on the basis of the constitution of own subsidiaries abroad. Normally, this kind of decision was based on the identification of all local resources and skills that were considered essential in defining the role that the subsidiary would assume in the corporate network. In many cases, the outsourcing of R\&D activities for the subsidiaries occurred as a result of the development of capacity and employee skills locally by the subsidiary, both in technology and in management. In other cases the outsourcing of R\&D occurred through partnership with universities or through contracting R\&D institutes.

This study was conducted in three subsidiaries of multinationals, located in the south of Brazil. The first subsidiary that was studied has the headquarters in Germany and started its operation in Brazil in the seventies through direct investment and by building its own plant. The second subsidiary, North American, opted for purchasing a local company, which had over thirty years of experience in the local market. The third analyzed company was formed through a joint venture contract between a U.S. company and a local one, which was already a leader in the market, based on sixty years of existence and operation. Through the methodology of multiple case studies, the research was carried out in order to examine the decision-making process in the headquarters abroad in order to outsource $R \& D$ activities to their subsidiaries.

In the first section of this paper are analyzed theoretical approaches of the organizational strategies. In the section that follows, arguments that support the decision to invest abroad are presented. Then, the most relevant factors and variables considered in the decision-making process are analyzed. In the fourth section, relevant variables concerning the decision of outsourcing R\&D activities are revised. Only then, the research method of the case study with the details of the achieved results is presented. The paper is finalized with the closing comments of the authors, in the seventh section.

\section{CONCEPTUAL DEVELOPMENT}

This chapter will present main theoretical foundations that guided the construction of the research. The first subsection will address the construction of organizational strategies and their variables, explaining its correlation with the internal and external environments of the organization. The following subsection analyzes FDI (Foreign Direct Investment) as one of the strategies adopted by organizations to enter foreign markets. In the third subsection decision making aspects will be examined, especially regarding the factors that influence the decision-profile. In the fourth and final subsection of this chapter the possibilities and feasibility of the outsourcing of the $R \& D$ activities will be evaluated. 


\subsection{FORMULATION OF THE ORGANIZATIONAL STRATEGY AND ITS VARIABLES}

As a consequence of the significant changes in external scenarios due to the emergence of new competitors, both in local and global markets, as well as due to changes in the consumer market which now requires greater variety, lower prices and better product quality, organizations in the last two decades coped with a new reality, being forced to adopt new ways of thinking about the market, the consumer and ways to operate.

Mintzberg (1973), one of the most prominent researchers in the process of strategic conception, emphasizes the need of matching strategy to the situation, which is more linked to a contingent perspective and suggests that strategic plans should specify general objectives and alternative routes, leaving the manager with flexibility to respond to a dynamic environment. Five years later, the author concluded that strategy could be seen as a consistent set of behaviors established by the organization for a certain period of time and strategic changes could be interpreted as responses to changes in the environment constrained by bureaucracy and action of leadership (MINTZBERG, 1978).

In the following decade, Porter (1989) defined two central issues that allow selecting competitive strategy based on: (i) the attractiveness of industries (industrial fields) in terms of profitability in the long term, and the factors that determine this attractiveness; (ii) the determinants of a competitive position within an industry. For the author, competition rules include five competitive forces: (1) entry of new competitors, (2) threat of substitutes, (3) bargaining power of buyers, (4) bargaining power of suppliers and (5) rivalry between existing competitors. The two basic types of competitive advantages, combined with the scope of activities of the firm, point to the three generic strategies in order to achieve the above-average performance in an industry: (i) leadership in cost, (ii) differentiation and (iii) focus (in cost or differentiation).

The organizational differences were also studied by Porter (1989) who identified, as one of their causes, the risk of the firm combining inconsistent management practices, such as: pattern of investment required by the company, profiles of executives to be recruited and trained, the company's organizational culture and organizational rules. The differences were explored in greater depth by Whittington
(2002) in theoretical approaches in different schools of thinking such as the classic, evolutionary, procedural and systemic schools, and complemented by Minzberg, Ahlstrand and Lampel (2000) in their book entitled "Strategy Safari", defining ten schools of strategic thinking, with emphasis on the importance of contextual and contingent processes of formulating strategy.

Whittington (2002), Kaplan and Norton (2004) studied the differences between the organizations and reinforced the importance of a systemic approach. They identified that the arrangement of resources in internal structures influences the setting of strategies and policies, including the micro politics of individuals and departments, social groups, as well as the interests and resources of the surrounding context. The systemic perspective includes classes and professions, nations and states, families and genders. A systemic approach with intra-organizational focus shows that no area of the organization is working isolated and that every action made by a department influences other organizational areas.

Berman and Hagan (2006) presented a model of a business strategy based on technology. The concept and principles of a process of business strategy combined with the vision of market and technological know-how allow companies to achieve cooperation between different organizational units and, this way, implement higher rates of innovation. This approach requires the recognition of the firm that innovation has become a critical factor for its sustainable growth and arises from the intersection of vision of the market and technological know-how. Exploring the relationship between technological innovation and strategy, Curry and Clayton (1992) defined three categories of technological strategies: (i) adopt and adapt; (ii) incremental innovation, (iii) innovate in a disruptive way. Each of these categories corresponds to significantly different attitudes and behaviors of business management. There are circumstances in which each one may represent the best strategy to be applied and, at the same time, each one has different levels of risk and cost.

\subsection{STRATEGY FOR THE FOREIGN DIRECT IN- VESTMENT}

In the last two decades it was possible to realize that the allocation of resources focused on the exploitation of economies of scale and scope was no longer sufficient to obtain results in the same proportion. Local and national markets could no longer ab- 
sorb the volume produced and corporate managers coped with the challenge of creating complex logistics structures for the distribution of the production, aiming at reaching more distant markets. Changes in communications and transport, accompanied by deliberate institutional innovations and technological changes have transformed the global scenario since the 60s, impacting the increase in the volume of investments in the internationalization of operations (SEAPERLANDA, 1993).

Seaperlanda (1993) examines the reasons that drive organizations to decide for undertaking direct investments in foreign countries and concludes that the decision is based on the Theory of Transaction Costs supported by the Evolutionary Theory, that is, the manager seeks for identifying the variables within the "make or buy" logic, at the same time that it considers the influence of asymmetry of the available information, the costs and characteristics of the human and material resources. The three most relevant factors considered in the decision process of directly investing in a foreign country, according to Dunning (1980), are: (i) the possession of specific and exclusive assets, (ii) the analysis whether it is more interesting "to make use of assets" or "hire/ sell them to another firm and purchase the product", and (iii) the comparison of the rate of profitability in the application of assets in the country of origin or in the country intended to receive the direct investment.

Wells (1998) warns on the risks that the decision of direct investments may involve, which are little investigated by theorists of the internationalization of operations. The main one is the political risk, changes of legal rules and taxes on production, exchange rates, laws regulating import and export procedures, environmental standards and labor laws. The risk of uncertainty to find suppliers in the same technological level should also be considered.

It is understood that the foreign investment made by multinational companies abroad is central to the development of many emerging economies. It provides the input of financial resources, new knowledge and technology in the host country. The variety of strategic objectives that motivate a multinational company to carry out direct investment in another country is reflected in different roles that can be played by the subsidiaries within the international corporations. When the multinational opts for the purchase of a local company, restructuring processes normally happen and are justified by the fact that the acquired firm denotes operational or management problems (MEYER, 2004).

Empirical evidence shows that these restructured companies receive new resources and begin to operate with higher productivity rates than in the past. According to the perception of Meyer (2004), another important issue with few empirical studies refers to the sharing of knowledge and technology between the head office and its subsidiaries. Multinational corporations have, as a practice, the training of local personnel at all levels, in addition to performing, periodically, training programs in the subsidiary, and temporary transference of experts and executives from the head office and subsidiaries, promoting and intensifying the exchange and sharing of information, experience and knowledge.

For Ghoshal (1987), an organization's industrial structure can exert significant influence on the design of the strategy, but at the same time, a deliberate strategy can influence the structure of the plant. The author recommends managers to focus on the issues of risk and learning as central pillars for the construction of corporate strategies. The results of the empirical research conducted by Egelhoff (1988) showed that companies which invest in their own industrial structures with the area of R\&D get higher rates of success in the diversification of product portfolio and an increased value of the goods commercialized in the foreign markets, than companies which adopt the strategy of production at the home country, only investing in marketing structures abroad.

Based on a series of empirical research projects, Melin (1992) concluded that the process of internationalization is characterized by a high degree of complexity, variability and variety, which, to be considered in the review process, require a holistic and longitudinal approach. Reinforcing this perception, Oakley, Larkins and Winkle (1999) recommend the assessment of their goals to multinational companies, in order to find the most appropriate design of the process of internationalization of their operations. Among the reasons cited by researchers, there is the differentiation of the range of skills and capabilities that the company needs in order to achieve success in the domestic and foreign markets.

The international experience of the headquarter's management team, as one of the factors that influ- 
ence on the decision to hold direct investment in another country, was evidenced in an empirical research conducted by Sambharya (1996). In the author's opinion, the results reinforce the perception in the way that the corporate decision reflects the personality and behavior of the decision-makers. The importance of managerial skills also appeared in the text of Rondinelli, Rosen and Drori (2001), mainly on the issue of alignment of domestic business strategies to the conditions of the external environment. In the case of lack of match between business strategy and the organizational structure and management processes, firms loose sales, reduce their market share, and increase their operating costs and non-conformities, in addition to hampering their relationship with customers and suppliers, generating internal conflicts, with the consequent loss of strategic focus.

For Rugman (2006), many of the multinational corporations were incorporated into traditional markets where the dominant strategic option was related to cost or differentiation. With the objective of preventing the entrance of competitors in the market, companies choose to adopt the strategy of competition on price and establish deals in order to form a cartel, at the expense of efficiency. Only recently the main focus started to be the operation with maximum efficiency and the creation of a competitive edge based on technology and knowledge. However, it was evidenced that multinationals transfer the most advanced technologies, initially, only to the subsidiaries located in developed countries where the absorptive capacity is higher than in developing countries.

Based on the results of empirical research on the strategy adopted by global companies, Collis (1991) observes that (i) companies choose to compete in non attractive markets if their resources shape the distinctive competitive advantage in these markets, (ii) the choice of strategy is influenced by the geographical location of the firm, (iii) the organizational structure will not be shaped immediately to the strategy, but will be gradually adjusted as the company focuses on appropriate steps to consolidate its competences and (iv) management structure (management based on the organizational culture) will drive the company to invest directly in other foreign countries and maintain the investment for a period of time during which it will not be possible to optimize production costs.

According to Hamel and Prahalad (1994), the vari- ables that should be considered in the process of redefining production strategies are: mergers and acquisitions, increasingly severe environmental legislation, reduction of protectionism, changes of consumer expectations, disruptive innovation in technology, emergence of trading blocks and the intensification of the world trade.

The report that examines the outsourcing of R\&D activities of US organizations to India (The Economist, 2004) highlights how arguments which are more relevant to the internationalization of research and development tasks in the construction of a careful strategy are needed to tackle the growing international competition in sectors such as software and pharmaceuticals, forcing companies to provide solutions and alternatives with lower cost and similar or even higher quality. According to the research of Blanchard et al. (2004), some of the surveyed organizations had the participation of eighty per cent of foreign $R \& D$ within the total budget of their organizational unit.

\subsection{FACTORS AND VARIABLES THAT INFLU- ENCE THE INTERNATIONALIZATION DECI- SION PROCESS}

The perception of uncertainty and the need of certainty may encourage the search for information as well as the development and/or design of projects as alternative solutions to specific problems. The contextual and situational variables play an important role both in the perception of risk and uncertainty as they influence the decision-making. But, in some ways, this finding contradicts the traditional model of decision making which is based on expected utility, more subjective in nature, where the individual chooses the alternative that presents (in his perception) higher expected utility. By linking the two theoretical approaches, it is possible to say that the decision seeks to find an optimal balance between the expected value of utility and the minimization of the risk and uncertainty. The variable time also influences the decision, based on its link with the uncertainty and the risk (MILBURN and BILLINGS, 1976).

O'Dell (1992) studied decision-making by consensus and identified factors that should be considered and addressed in that decision process. The first one refers to the professional experience and the level of maturity of the people who are part of the group. The views and perceptions of more experienced and older people have more influence in the choice of al- 
ternatives in the decision-making process. The second factor is the uncertainty of mid-level executives who tend to opt for choices which they perceive as more aligned with the way of thinking of top executives. The third factor relates to the ego of executives and managers who seek to take into account, as the main criteria in the selection of alternatives for a decision, the result or impact that such decision may have on their careers or personal lives. The fourth factor refers to the resistance of executives to change their initial view, based on a kind of personal insecurity regarded the fact that any change of opinion can represent the expression of failure or weakness.

According to Mostaghimi (2001), studies conducted at the psychological dimension show that the process of gathering information to support decisionmaking influences the decision itself. Most studies are conclusive at affirming that the information collected through interaction, unlike the gathering held by documentary analysis, for example, shows potential to change the decisions of the ones who decide.

Nel, Pitt, Berthon and Prendergast (1996) argue that the decision-making process involves multiple actors who participate in different ways and at different points in the process. There is the possibility that various functional areas can take alternative positions and roles during the decision-making process, becoming available to decision-makers to be required, depending on the complexity of the problem or the available alternative solutions.

The classical approach of decision-making, based on the rational behavior to conceive specific solutions, can lead to failure if it ignores or underestimates the influence of unknown or subjective variables. It is understood that the tendency to try preventing the inclusion of the subjective or little known variables in the decision-making process is explained by the absence of a more robust theoretical framework and the insecurity caused by uncertainties arising from a higher degree of complexity of the scenarios to be evaluated in the decision making process. Moreover, we perceive that the objectivity regarding the interpretation of "success" of the decision-making usually presents more concrete and measurable results, influencing the perception of managers about the variables which influence the decision-making process. However, the results of surveys and studies attest that decision-making is essentially subjective and includes a high degree of uncertainty (TRULL, 1966).

\subsection{ANALYSIS OF THE DECISION OF EXTERNA- LYZING R\&D ACTIVITIES}

The expansion of the role of R\&D and its integration to the organizational universe can be interpreted as a multidisciplinary concept of the area, where each one in the organizational unit contributes to the development of new products and operational processes. However, it is important to highlight the theoretical bases that can translate these advantages of the organizational integration for the institutional decision-making, in particular, for a decision on how to carry out R\&D activities.

The first and most recurrent explanation, made at the light of the theory of transaction costs, derived from Coase's (1937) Theory of the Firm, recommends the purchase of products and services from the market when internal costs are higher than those practiced outside. It is evidenced that, if the decision-making process is focused only on the operational costs, the option of purchasing R\&D services in the market, instead of carrying them out internally, will almost always be favored. Therefore, following the same theoretical approach, the firm will tend to grow when the costs of internal transactions are lower than those in the market.

Following the same thinking, the firm must also choose to do R\&D internally when the transactions are frequent, uncertain and require special investments, that is, specific assets (SWEDBERG, 2003). Otherwise, it is recommended to purchase these services from the market. However, several authors present important counterpoints, as, for example, Alchian and Demsetz (2005) who, based on the theory of agency, identified increased costs due to the need of internal oversight and control of internal processes. Katz and Piepoli (1995), Jones (2000), Anik (2002), Morrison (2002) and Kramer (2002) also show the dominance of economic reasons for making the decision of outsourcing $R \& D$, pointing to the advantages of reducing the administrative personnel structure and also the lesser involvement of the manager.

One of the authors who examined the option of carrying out the activities of foreign $R \& D$ is Howells (1999) who perceives it as part of a broader vision and highlights four reasons to justify the decision in doing so: (i) growth, both absolute and relative, of the outsourcing of R\&D in industrialized countries, making this alternative increasingly representative, (ii) the approach of $R \& D$ as a function and corporate 
activity that is changing, and therefore can no longer rely only on internal knowledge, and (iii) the importance of the role of R\&D in the creation and development of the research market, (iv) the consolidation of firms dedicated to perform R\&D contracts.

Barney and Hesterly (2004) observed that the superior performance of a firm relies on the resources and capabilities, which have to be valuable, rare, expensive to imitate and without substitutes, thus representing strategic resources of the organization. At the same time, it is possible to verify that the specificity of these assets may prevent the outsourcing process, as highlighted by Williamson (1996), who pointed to the contractual need in order to reduce the risk of the contracted firm. This situation applies directly to R\&D activities, because of the specificity of the characteristics of infrastructure which are essential to conduct the research process, what can in this way represent a real obstacle to its outsourcing.

Boath, Hess and Munch (1996) emphasized the proper use of the organizational resources as main advantages of the outsourcing of the $R \& D$ activities, performed in a more flexible and efficient way, providing even cost reductions. They argue that the company should focus its efforts on the internal R\&D research of strategic products and central to the firm, outsourcing all other developments, on which they are supported by Harris et al. (1996) who have found out that the outsourcing of the R\&D enables the achievement of higher productivity rates, what, on the other hand, leads to risks of dependency and new vulnerabilities. So, they recommend that the decision to outsource $R \& D$ be based on the following variables: the centrality and importance of the research to the organization, the strategic role of competence that comes from research and the added value of the technology that results from the research.

Adopting a more conservative position, Narula (2007) recommends the combination of the internal, external and quasi-external R\&D activities to the organization so that it can improve the relation between budgeting and the investment process in order to aid in maintaining its competitive position in the long term. To the authors who agree with this approach, the decision on how to carry out $R \& D$ should also be considered: (a) distribution of the organizational capabilities that the company has, (b) development of the individual technologies and changes in the technology characteristics following the passage of the new technology into the mature technology, (c) strategic and economic issues related to the competitive environment.

However, as a counterpoint to these positions and arguments, it is worth citing the report of Johnson (2004) about the prospect of R\&D activities in ninety-eight industries associated to IRI - Industrial Research Institute in the United States from 1999 to 2004, which shows that corporations prefer to internalize the activity because they believe this provides an important competitive strategic advantage.

Jonash (1996) and Carayannis et al. (2000) note that most of the managers responsible for $R \& D$ are reluctant to outsource R\&D activities due to the lack of control over the process and lack of trust in the contracted firm. A survey that was conducted with forty companies in New Zealand (25 small ones, 10 medium size, and 5 large companies), led by Davenport, Davis and Grimes (1999), showed that the process of outsourcing R\&D by the firms together with universities and research institutes, was being negatively influenced by the lack of confidence in the competence of the research institutes for implementing the planned activities, which suggests that outsourcing of the R\&D activities has to be examined in the light of multidimensional trust. The results of Klofsten, Jones-Evans and Scharberg (1999) emphasized the importance of the trust factor in the process of interaction among firms and universities, showing evidence that the contracting of $R \& D$ services activities between firms and universities happened because of the informal contacts between chief executive officers and researchers. The research of Vardzel (2000) highlights the influence of the size of the company (the larger, the better) to achieve success in R\&D outsourcing based on trust and quality of the communication between the contractor and hired parties.

The importance of the trust as a variable is also emphasized in surveys conducted in Brazil. Brisolla, Corder, Gomes and Mello (1997) observe that the process of outsourcing $R \& D$ with universities occurs due to the personal contacts among students and teachers with the firms, and Dagnino and Gomes (2003) report the case of interaction of an organization with the university on which the importance attributed by the company to the faculty is based on the degree of specialization of the researchers, which transmits greater security and confidence in the competence of the university.

To solve the problem of trust in relations between contractor and a potential contracted firm in the R\&D 
contracts, especially based on the technical competence, Griest and Liou (1998) emphasize the importance of maintaining control of the process of R\&D activities' outsourcing to companies certified by international standards of quality, and recommend that firms which contract them should: (i) involve the contracted firms for carrying out R\&D following the procedures of normalization of ISO and providing conditions and guidelines to ensure meeting requirements for the deployment and maintenance of the quality process, (ii) share their strategic objectives with the contracted firms enabling them to understand contractor's procedures and norms and (iii) establish internal policies of HR in order to reduce possible discrimination and discomfort of employees in relation to external researchers and (iv) require compliance with standards and legal procedures in the process of $R \& D$.

\section{METHOD}

The method chosen for the research was a case study due to the methodological alignment with the goal and the questions that guided the study. Key elements of the research relate the evaluation of the internationalization process of the R\&D activities, based on variables that include the theoretical bases of cost of transactions and the development of capabilities and skills by Brazilian subsidiaries in the process of designing and modeling corporate strategies at their headquarters abroad.

According to Goode (1975), case studies cannot be considered a specific research technique, but a way of organizing social data, preserving the unitary character of the studied social object. The same perception is presented by Hartley (1994) for whom the approach of case study is not a method itself, but a strategy for the research, consisting on a detailed investigation of one or more organizations or groups within an organization, with the objective of providing an analysis of the context and the processes involved in the phenomenon to be studied. Also Yin (2005) highlights the adequacy of the case study method to investigate contemporary phenomena within the context of real life, mainly when the frontline between the phenomenon and the context is not clearly defined.

By comparing case study with other methods, Yin (2005) emphasizes the importance of preliminary analysis of the issues selected for the research on which the research method will be applied. Yin (2005) believes that case study is adequate to answer questions like "how" and "why", which are explanatory questions and deal with operational relationships that are verified along the time, rather than in a determined frequency. Concerning the formulation of questions for a case study, Stake (2005) demonstrates the understanding that they are complex, specific and well defined relationships, and that attention should be paid to ordinary experiences and to the knowledge fields. It is also emphasized that the selection of issues is crucial for the success of the research.

The case study was conducted in three industries situated in the metropolitan area of Porto Alegre. All industries are very important, both at economic and social aspects, in the regional and national terms. Their products are destined for local market and for export. The economic importance of the three companies was the first criteria adopted the researchers in the selection process, added to the availability of the firms to participate in this academic research. However, this agreement was followed with the requirement to avoid the disclosure of their corporate names.

The research was conducted in two stages: (i) a technical visit, with presentations on the organizations and visits to the operational departments, (ii) an indepth interview with the manager indicated by the director's board, responsible for the R\&D unit. Each interview took about two hours, with notes taken and registered in the notebook. Within six hours from each interview notes were transcribed, coded and analyzed following recommended procedures for discourse analysis which was considered the most appropriate for the purpose of the research, searching comprehension of an underlying reality, based on the understanding that every activity of the research represents a reality that is mediated, in some way, by researcher's interpretation (BARDIN, 2004).

Company ALPHA is now the largest producer of specific appliances in the world. It was founded in Germany in 1926 and currently has subsidiaries in Brazil, Switzerland, Austria, the U.S. and China. The Brazilian subsidiary was the first international expansion of the company, having been settled in 1973 and started operation in 1975. Products destined to the high-quality professional segment are manufac- 
tured in the German headquarters. Operations in the United States focus on the hobby segment and Brazil and China produce for the low-tech professional market. Today the corporation employs 9.000 employees, 1.200 being allocated in the Brazilian subsidiary. Currently, each corporation's subsidiary is specialized in the production of final products or components in which each of them must demonstrate high level of competitiveness through the combination of several factors, besides reduced production cost.

BETA, founded in 1990, is a global manufacturer and distributor of agricultural equipment and the respective spare parts. Its headquarter is in Georgia, and it has been present in the Brazilian market since 1996, when it acquired a Brazilian company of the same industry located in the metropolitan area of Porto Alegre. The American corporation always adopts this kind of "modus operandi" in its process of internationalization, that is, through the acquisition of foreign firms already in operation and with consolidated positions in local markets based on their own recognized brands in these markets. Nowadays, BETA operates in Brazil with three industrial plants, offering a portfolio of products focused on agriculture, including tractors, harvesters, hay and forage equipment, sprayers, equipment for the preparation of the soil and implements. In this segment, the corporation has $28 \%$ of the market-share of the U.S. market and $20 \%$ of the European market. Local production is focused on the CKD system (assemblies and parts - 80,000 units per year) and light-duty vehicles $(4,000$ units per year in average). Of the 22 brands that sell worldwide, 13 are manufactured in Brazil.

The third researched company is GAMMA, which is also an U.S. multinational. It is currently the world's largest producer of specific products, having started operation in Brazil in 1983, through a joint venture with a local Brazilian firm. Nowadays, GAMMA has a staff of 210,000 people allocated in its 90 plants worldwide and more than 36 billion dollars of annual earnings. It is worth mentioning that the strategy adopted by the company in the process of internationalization is based on the acquisition of firms with variable participation in local companies (in Saudi Arabia it is a minority partner) that already operate in the local market and with their own, already consolidated, brands in the targeted market. Today, the Brazilian subsidiary of GAMA is the larg- est manufacturer of specific products in Brazil, with 2 factories (Canoas and Manaus), 3 commercial subsidiaries, 53 brand stores, 950 employees and 160 domestic suppliers.

\section{RESULTS}

After the early stages of internationalization through export operations, ALPHA decided to establish its own operations abroad. The location of the first subsidiaries was decided on the basis of cultural proximity - with a predominance of German cultural traits and language (south of Brazil, Switzerland and Austria) and the possibility of implementing an operational process that involves an assembly line. More recently the criteria changed and decisions are now based on market opportunities, production and distribution costs, availability of the workers and of the qualified operational partners (USA, China).

BETA resulted from the acquisition of a German subsidiary in the United States by an U.S. company. Soon afterwards, it consolidated its position in the American domestic market and spread to foreign markets through exports. The level of success in these operations demanded changes in its internationalization strategy. However, the selected method differed from ALPHA's option, through the decision to acquire already working operations, with already consolidated brands. The Brazilian subsidiary, which was acquired by BETA in 1996, had operated in Brazil since 1961 and owned manufacturing know-how, knowledge of the specificities of the local market and had an efficient distribution network throughout the national territory.

The Brazilian subsidiary of GAMMA has operated in the local market in the segment of industrial cooling since 1934, becoming a national reference in the sixties for producing specific products. In 1983, the company established a joint venture with the American multinational GAMMA. Joint ventures was adopted by GAMMA to address new markets, opting for association or acquisition of companies that already operate in the local markets, with their own consolidated brands in the target market.

Analyzing the decisions of the three companies, it is possible to perceive the alignment with the theoretical concepts of Seaperlanda (1993), who highlights the theory of transaction costs as the background to the strategy of internationalization of operations. Only in the case of ALPHA, whose decision to internationalize operations go back to the nineteen sev- 
enties, the relevance of the variable of cultural proximity (descendants of Germans in southern Brazil) is evidenced. This approach is also confirmed with the theory of Rugman (2006) for whom the majority of multinational corporations are looking for traditional markets with the dominant strategic choice of cost or differentiation.

In the three surveyed companies, it was possible to evidence the transference of R\&D activities from the headquarters to the subsidiaries. However, this process did not happen softly and naturally as it could be a priori thought, due to the parental links between them. It was found that information sharing, considered essential concerning the portfolio of products and operational processes, happened in a non-linear way. Idiosyncratic characteristics, intrinsic to each of the researched organization, influenced configuration of the process of knowledge transference and construction of the local know-how.

The original strategy of the German company ALPHA was to assign to the Brazilian subsidiary only the assembly of equipment modules, with the minimum requirement of expertise of the local workers, in technological terms. This was the position of the German headquarters in the seventies, which is alligned to the theoretical approach of Oakley, Larkins and Winkle (1999), who recommend to multinational companies the evaluation of their goals in order to find the most appropriate design of the internationalization process of their operations.

However, over the decades, the Brazilian operation prospered and it was possible to verify that the adopted "modus operandi" resulted in very high costs, which, in turn, meant a reduced profitability margin of the operation site. Thus, within the logic that highlighted the economic rationality, headquarters chose to invest in subsidiaries and transform them from a mere assembler to a factory. This decision implied greater investment, better infrastructure and organization in general, not only in operational terms, but also in the commercial and management process. The Brazilian subsidiary became responsible for supplying products destined to the Brazilian and Latin-American markets, requiring a better preparation of the local staff, due to the implementation of control procedures and improvement of the management process of local resources and assets.

The decision is aligned with the theoretical approach of Meyer (2004) and Silveira, Sbragia and Costa (2008) who found evidences that when a multina- tional corporation decides to delegate some of the operations to a foreign subsidiary, this decision is accompanied by investments to restructure the local process, justified by the fact that the subsidiary normally presents operational and management problems. The decision to restructure operations of the new subsidiary is also supported by Ghoshal (1987) who showed that the industrial structures can exert significant influence on the design of the strategy, but, at the same time, a deliberate strategy can influence the structure of the industry.

This decision, which happened at the end of the eighties and early nineties, did not involve more complex activities, such as the tests of various products and their components, nor R\&D activities. However, in the second half of the nineties, as a result of changes occurred in the environmental legislation in Germany, which emphasized the imposition of deadlines to adequate all products to new patterns approved in order to reduce the potentially polluting waste, the headquarter was obliged to invest in R\&D process. The alternatives were: (i) contract German researchers, (ii) contract research institutes in Germany outsourcing R\&D activities, (iii) outsource R\&D to its own subsidiaries in other countries.

The first alternative would increase the company's fixed cost for an indefinite period due to Germany's labor law, which implies on contractual guarantees to the workers for an indefinite period of time, resulting in employment stability, regardless of the further need of these workers in the organization. Considering the fact that these researchers would be needed only for a determined period of time, and would expire at the moment in which all products met new statutory requirements, this option was discarded.

The second alternative was considered of very high cost and little control over deadlines for completing the contracted tasks, besides involving the risk of leakage of confidential information. Despite this negative aspects, the corporation contracted several research institutes in Germany due to their high level of excellence and technological standards. However, this contract was made only in a few cases and especially when alteration of the product was considered as having a high degree of complexity.

The third option was object of fierce resistance from German technicians and researchers, mainly based on the belief that their colleagues from foreign subsidiaries, as, for example, in Brazil, lacked technical 
competence to develop complex activities, such as R\&D activities. The argument that favored this alternative was the flagrantly lower cost of Brazilian researchers, in addition to the Brazilian labor legislation, that allows hiring people for a determined period of time and including the possibility of firing out workers without any fair cause.

The described process was also found in the research conducted in Brazil by Borini, Fleury, Fleury and Oliveira Jr. (2008) who verified that the subsidiaries in this country are characterized by high level of integration with their headquarters abroad, reducing the level of their autonomy and initiative. This situation also reflects Narula's (2007) arguments that recommends an appropriate "dose" of internal, external and quasi-external R\&D activities for the organization, in order to search balance in the process of calculating the budget of investment to maintain the company's competitive positioning in the long term. In this sense, the decision on how to carry out R\&D should also consider: (a) physical distribution of different types of capabilities and competencies of the firm; (b) development of specific technologies and evolution of the characteristics of the technology as it matures; (c) strategic and economic issues related to the competitive environment.

In order to circumvent the lack of local expertise, several German researchers were transferred to Brazil to coordinate R\&D activities and, at the same time, Brazilian employees were transferred to work in the German headquarters. Also more researchers were hired at the Brazilian subsidiary in order to enable the Brazilian R\&D unit to cope with new $R \& D$ challenges, a decision that is supported by the model based on recommendations from Davenport, Davis and Grimes (1999) regarding the influence of the multidimensional confidence on the decision about how to carry out R\&D process. Klofsten, JonesEvans and Scharberg (1999) also emphasize the importance of the variable confidence in hiring of the R\&D services. In addition, Vardzel (2000) highlights the influence of the size of the company (the larger the better) to the success of outsourcing R\&D, based on trust and quality of communication between the firm and the contracted party.

At BETA, the process of transferring R\&D activities to the Brazilian subsidiary occurred in a different way. BETA resulted from the acquisition of a Brazilian company that had been already operating in Brazil and Latin America for more than thirty years, with facilities and specialized workers to manufac- ture the whole portfolio of products, in addition to the distribution network of these products to the clients. The interest in the acquisition was based on the relevance of the Brazilian company, considering the market share that the American corporation sought. Thus, the decision process was structured to take all these aspects into account.

Based on the detailed assessment of the local competencies and capabilities, in terms of infrastructure, technology and personnel, the U.S. headquarters chose to transfer a set of R\&D activities to the new subsidiary and even decided to implement a high tech research center in the Brazilian subsidiary, with a significant input of resources for this purpose. The similarity of this process of know-how sharing and R\&D activities transfer to ALPHA can be observed in the cross-transfer of professionals (from the United States to Brazil and vice versa).

On the other hand, the main difference between them is related to the development of local partners and their inclusion in the execution of $R \& D$ activities for the line of products manufactured in the Brazilian subsidiary. While at ALPHA know-how transfer was restricted to the Brazilian subsidiary and its employees (suppliers of the main components and even raw materials, such as steel, were kept the same that already supported the German operation), at BETA, no restrictions in the process of development of local partners could be verified subjected to the certification of the suppliers by international standards and rules required by the organization in terms of technology and also in terms of control and management processes.

The process at GAMMA Corporation also presents characteristics that highlight differences in relation to the "modus operandi" found at ALPHA and BETA. The main difference consists in the "evolutionary focus" and the emphasis on gradual learning by the local employees. A similar model was already observed by Griest and Liou (1998), who evidences the importance of maintaining control over the process in the outsourcing of R\&D activities and recommends sharing its strategic goals with the contracted firms besides a more intense action of the HR area, in order to facilitate the learning process.

Similarly to BETA, GAMMA resulted from the acquisition of the local Brazilian firm by the foreign corporation. An initial evaluation showed several inefficiencies and deficient operational and managerial processes, which obliged the American corpora- 
tion to adopt the same policy used by ALPHA and BETA: cross-transfer of employees (from the United States to Brazil and vice versa). However, unlike what happened at BETA, where the main motivation was to share knowledge with the purpose of transferring cultural values and, only afterwards, technology and know-how, at GAMMA the main purpose was to adjust the operations in the Brazilian subsidiary, reorganize management and fix up operational inefficiencies.

The three researched multinationals, ALPHA, BETA and GAMMA, which all have subsidiaries in Brazil, adopted different methods to transfer R\&D activities to their subsidiaries, but with the same result. Through the improvement of conditions, either technological or the level of knowledge of employees, the subsidiaries gained the confidence of the headquarters and received autonomy and responsibilities for conducting R\&D activities as showed in the Table 1 below:

Table 1: Most relevant aspects of the outsourcing of the R\&D activities to the Brazilian subsidiaries

\begin{tabular}{|c|c|c|c|}
\hline $\begin{array}{l}\text { The most relevant } \\
\text { aspects }\end{array}$ & Alpha & Beta & Gamma \\
\hline Headquarters & Germany & United States of America & United States of America \\
\hline $\begin{array}{l}\text { Original form of } \\
\text { outsourcing }\end{array}$ & $\begin{array}{l}\text { Starting Brazilian unit } \\
\text { for assembling parts } \\
\text { imported from Germany }\end{array}$ & $\begin{array}{l}\text { Acquisition of a well } \\
\text { established local firm, } \\
\text { with a good network } \\
\text { of distributors and } \\
\text { recognized brands }\end{array}$ & $\begin{array}{l}\text { Acquisition of a well } \\
\text { established local firm, } \\
\text { with a good network } \\
\text { of distributors and } \\
\text { recognized brands }\end{array}$ \\
\hline $\begin{array}{l}\text { Decision to outsource } \\
\text { R\&D activities }\end{array}$ & $\begin{array}{l}\text { Not planned - without } \\
\text { better options among } \\
\text { those available to } \\
\text { adapt products to the } \\
\text { environmental legislation }\end{array}$ & $\begin{array}{l}\text { Deliberated - focusing } \\
\text { transfer on cultural } \\
\text { values from the } \\
\text { headquarters }\end{array}$ & $\begin{array}{l}\text { Deliberated - focusing } \\
\text { on the adjustment } \\
\text { of operations, } \\
\text { reorganization of the } \\
\text { local operational and } \\
\text { solution of management } \\
\text { inefficiencies }\end{array}$ \\
\hline Divergent aspects & $\begin{array}{l}\text { Low level of local } \\
\text { interaction }\end{array}$ & \multicolumn{2}{|c|}{$\begin{array}{l}\text { High level of interaction - developing partners and } \\
\text { suppliers }\end{array}$} \\
\hline Convergent aspects & \multicolumn{3}{|c|}{$\begin{array}{l}\text { Decision based on the evaluation of the local expertise and capabilities; } \\
\text { Cross-transfer of personnel between headquarter and subsidiary. }\end{array}$} \\
\hline
\end{tabular}

From the results of the research, it was possible to verify that the improvement of local conditions (technological and learning of the employees to absorb new activities), in terms of complexity and scope, allows more responsibility and activities to be transferred to a subsidiary, as happened with the outsourcing of the R\&D activities to the Brazilian subsidiaries. As it could be observed, this process culminated even with the installation of one of the global centers for research and development in the Brazilian subsidiary followed by the assignment of the local team of workers to coordinate a global product project, at GAMMA.

\section{CONCLUSION}

The process of internationalization of operations is decided considering a set of variables whose breadth and scope depend on the type and form of the objectives that the international organization aims to achieve. In the case of the internationalization through foreign direct investment, some topics need to be considered, such as the costs of the inputs, raw materials and the structure of suppliers, availability, knowledge level, capabilities, competencies and skills of the human resources, logistics costs in manufacturing, tax and labor law, all kinds of governmental incentives, consumer market and its characteristics, in addition to political risks and economic context, among others. 
It is worth mentioning that the decision to internationalizing operations, regardless of the type, shape or size, implies conceiving strategies based on the organization's purposes, considering its involvement with the market. Research evidenced that a higher level of involvement of the organization with a specific market abroad, characterized through established relations based on the trust toward local expertise, regardless of being pre-existant or needing to be developed, result in more complex activities being transferred to the subsidiaries, such as research and development.

The authors believe the focus of the present research is relevant, deserving the attention from other researchers, who could contribute with further research to the design of new frameworks for the management of international operations and R\&D units that could lead to greater autonomy of the subsidiaries of the multinational corporations in Brazil.

Considering that the selection of the firms that were the object of this study was not at random (they were picked-up deliberately, for convenience), the authors suggest carrying out further researches on Brazilian subsidiaries of multinational companies that outsource R\&D activities, in order to identify the main variables involved in the decision-making process.

\section{REFERENCES}

ALCHIAN, Armen A.; DEMSETZ, Harold. Produção, custos de informação e organização econômica. Revista de Administração de Empresas, v. 45, n. 3, p. 70-92-108, 2005.

ANIK, Shabbir T. A new map for creating sustainable competitive advantages. Pharmaceutical Technology North America. 2002. p.24

BARDIN, Laurence. Análise de conteúdo. 3. ed. Lisboa: Edições 70, 2004.

BARNEY, Jay B.; HESTERLY, W. Economia das organizações: entendendo a relação entre organizações e a análise econômica. In: CLEGG, S.; HARDY, C; NORD, D. (Orgs.) Handbook de estudos organizacionais. São Paulo: Atlas, 2004. v. 3, p. 131179 .

BERMAN, Saul J.; HAGAN, Jeff. How technology-driven business strategy can spur innovation and growth. Strategy $\mathcal{E}$ Leadership, v. 34, n. 2, 2006.

BLANCHARD, P.; HUIBAN, J. P.; SEVESTRE, P. R\&D and productivity in corporate groups: an empirical investigation using a panel of French firms. Artigo submetido à publicação na edicação especial de Annales d'Economie et de Statistique. Primeira versão: Agosto de 2003. Esta Versão: Maio 2004.
BOATH, David; HESS, Phil; MUNCH, Craig. Virtual R\&D: a core competency approach to outsourcing. Pharmaceutical Executive. v. 16, n. 6, p. 72-75, Jun, 1996.

BORINI, Felipe Mendes; FLEURY, Maria Tereza Leme; FLEURY, Afonso; OLIVEIRA JR., Moacir Miranda. The relevance of subsidiary initiative for late-movers: an analysis of the Brazilian multinationals. In: Anais XXXII ENANPAD, 2008.

BRISOLLA, Sandra; CORDER, Solange; GOMES, Erasmo; MELLO, Débora. As relações universidade-empresa-governo: Um estudo sobre a Universidade Estadual de Campinas (Unicamp). Educação \& Sociedade, ano XVIII, nº 61, Dezembro/1997.

CARAYANNIS, Elias C.; ALEXANDER, Jeffrey; IOANNIDIS, Anthony. Leveraging knowledge, learning and innovation in forming strategic government-university-industry (GUI) R\&D partnerships. Technovation 20 (2000) 477-488.

COASE, R. H. The nature of the firm. Economica, v.4, 16, p.386$405,1937$.

COLLIS, David J. A resource-based analysis of global competition: the case of the bearings industry. Strategic Management Journal (1986-1998); Summer 1991; 12, SPECIAL ISSUE.

CURRY, Simon J.; CLAYTON, Richard H. Business innovation strategies. Business Quarterly; Winter 1992; 56, 3.

DAGNINO, Renato; GOMES, Erasmo. A relação universidadeempresa: comentários sobre um caso atípico. Gestão \& Produção. Volume 10, num. 3, p.283-292, dez. 2003.

DAVENPORT, Sally; DAVIES, John; GRIMES, Charlotte. Collaborative research programmes: building trust from difference. Technovation 1999; 31-40.

DUNNING, John H. Toward an ecletic theory of international production: some empirical tests. Journal of International Business Studies (pre-1986); Spring 1980; 11.

EGELHOFF, William G. Strategy and structure in multinational corporations: a revision of the stopford and wells model. Strategic Management Journal (1986-1998); Jan/Feb 1988; 9, 1.

GHOSHAL, SUMANTRA. Global strategy: an organizing framework. Strategic Management Journal (1986-1998); Sep/Oct 1987; 8,5 .

GOODE, William Josiah. Métodos em pesquisa social. 5. ed. São Paulo: Ed. Nacional, 1975. 488 p

GRIEST, Debra L.; LIOU, Andrew Y H. The impact of contracting on quality transformation in R\&D. Quality Progress; may 1998; 31, 5; pg. 75.

HARRIS, R Clark; RICHARD, C.; MORONE, Joseph; WERLE, Michael J. The virtual R\&D laboratory. Research Technology Management; Mar/ Apr 1996; 39, 2; pg. 32.

HARTLEY, Jean F. Case studies in organizational research. In: CASSELL, Catherine \& SYMON, Gillian (Ed.). Qualitative methods in organizational research: a practical guide. London: Sage, 1994. 253p. p. 208-229.

HOWELLS, Jeremy. Research and technology outsourcing. Technology Analysis \& Strategic Management; Mar 1999; 11, 1; pg. 17. 
JOHNSON, Albert L. Industrial research institute's R\&D trends forecast for 2004. Research Technology Management; Jan/Feb 2004; 47, 1; pg. 17.

JONASH, Ronald S. Strategic technology leveraging: making outsourcing work for you. Research Technology Management; Mar/Apr 1996; 39, 2; pg. 19.

JONES, Oswald. Innovation management as a post-modern phenomenon: the outsourcing of pharmaceutical R\&D. British Journal of Management; Vol. 11, 341-356, 2000.

KAPLAN, Robert e NORTON, David. (2004). Mapas estratégicos: convertendo ativos intangíveis em resultados tangíveis. Rio de Janeiro: Elsevier, 2004.

KATZ, Philip H.; PIEPOLI, Michele. Drug \& Cosmetic Industry. New York: Apr 1995. Vol. 156, Num. 4; pg. 32, 3 pgs.

KLOFSTEN, Magnus; JONES-EVANS, Dylan; SCHARBERG, Carina. growing the linkoping technopole - a longitudinal study of triple helix development in Sweden. Journal of Technology Transfer; Aug 1999; 24, 2-3; pg. 125

KRAMER, Greg. Outsourcing R\&D. Appliance Manufacturer; Aug 2002; 50, 8; pg. 60.theory. Organization Studies, v.19, n.5, p.743-767, 1998.

MELIN, Leif. Internationalization as a strategy process. Strategic Management Journal; Winter 1992; 13.

MEYER, Klaus E. Perspectives on multinational enterprises in emerging economies. Journal of International Business Studies. (2004). Palgrave Macmillan Ltd.

MILBURN, Thomas W; BILLINGS, Robert S. Decision-making perspectives from psychology. The American; Sep/Oct 1976; 20, 1; pg. 111

MINTZBERG, H. Strategy-making in three modes. California Management Review, v. 26, n. 2, p. 44-53, 1973.

MINTZBERG, Henry. Patterns in strategy formation. Management Science, 1978, v.24, n.9.

MINZBERG, Henry; AHLSTRAND, Bruce; LAMPEL, Joseph. Safári de estratégia: um roteiro pela selva do planejamento estratégico. Porto Alegre: Bookman, 2000.

MORRISON, Scott. Outsourcing growth keeps prognosis upbeat. Chemical Week. New York: Feb 27, 2002. Vol. 164, Num. 8; pg. 74, 1 pgs.

MOSTAGHIMI, Mehdi. Information collection strategic design in experts-assisted decision making paradigm. Group Decision and Negotiation; Sep 2001; 10, 5; pg. 375

NARULA, Rajneesh. Choosing between internal and non-internal R\&D activities: some technological and economic factors. Disponível em: www.ingentaconnect.com/content. Acesso em 14/05/2007.

NEL, Deon, PITT, Leyland F., BERTHON, Pierre, PRENDERGAST, Gerard. Social decision schemes and group processes: some impacts on decision making. Journal of Managerial Psychology. Bradford: 1996. Vol. 11, Num. 6; pg. 4
O'DELL, William F. Effective business decision making. Small Business Reports; Mar 1992; 17, 3, pg. 68.

OAKLEY, Ellwood F III; LARKINS, Ernest R; WINKLE, Gary M. Issues in managing the multinational corporation. The CPA Journal; Jan 1999; 69, 1.

PORTER, Michael E. Vantagem competitiva - criando e sustentando um desempenho superior. Rio de Janeiro: Campus, 1989.

PRAHALAD, C K; HAMEL, Gary. Strategy as a field of study: Why search for a new paradigm? Strategic Management Journal; Summer 1994; 15, pg. 5

RONDINELLI, Dennis; ROSEN, Benson; DRORI, Israel. The struggle for strategic alignment in multinational corporations: managing readjustment during global expansion. European Management Journal Vol. 19, No. 4, pp. 404-416, 2001

RUGMAN, Alan M. Multinational enterprise strategy for developing countries. Multinational Corporations and Global Poverty, edited by Subhash C. Jain and Sushil Vachani, March 2006.

SAMBHARYA, Rakesh B. Research Notes And Communications Foreign Experience Of Top Management Teams and International Diversification of US Multinational Corporations. Strategic Management Journal (1986-1998); Nov 1996; 17, 9.

SEAPERLANDA, Anthony. Multinational enterprises and the global market. Journal of Economic Issues; Jun 1993; 27, 2; pg. 605

SILVEIRA, Franciane Freitas; SBRAGIA, Roberto; COSTA, Daniela Dutra. Estratégia de Entrada de Empresas Multinacionais em Mercados Emergentes: O Estudo do Caso Intel. XXXII ENANPAD, 2008

STAKE, Robert E. Qualitative case studies. In: DENZIN, Norman K.; LINCOLN, Yvonna S. (Eds.)The Sage Handbook of Qualitative Research: Third Edition. London: Sage, 2005. p.443-466

SWEDBERG, Richard. Economic versus sociological approaches to organization theory. In: TSOUKAS, Haridimo; KNUDSEN, Christian (Eds). The Oxford handbook of organization theory. Oxford: Oxford University Press, 2003. p.373-391

THE ECONOMIST. BUSINESS: Innovative India; Research and Development. London: Apr 3, 2004. Vol. 371, Num. 8369; pg. 67.

TRULL, Samuel G. Some factors involved in determining total decision success. Management Science (pre-1986); Feb 1966; 12, 6; pg. B270

VARDZEL, Gerald J. Trust: The secret of success for contract research organizations. Pharmaceutical Technology. Cleveland: 2000. pg. 44, 2 pgs.

WELLS, Louis T Jr. Multinationals and the developing countries. Journal of International Business Studies; First Quarter 1998; 29, $1 ;$.pg. 101

WHITTINGTON, Richard. O que é Estratégia. São Paulo: Pioneira Thomson Learning, 2002. Capítulo 2 - Teorias sobre estratégia, p.11-48. 
WILLIAMSON, Oliver E. Economics and organization: a primer. Califórnia Management Review, v.38, n.2, p.131-146, 1996.

YIN, Robert. Estudo de caso: planejamento e métodos. Porto Alegre: Bookman, 2005.

\section{AUTHOR'S BIOGRAPHY}

Dusan Schreiber is Professor of Strategy Management at Faculdade IENH, Novo Hamburgo, Brazil. He is also doctoral student at Universidade Federal do Rio Grande do Sul - UFRGS and director of South Konsult - Consultoria Empresarial Ltda. He has extensively published nationally and internationally in Conferences on Management in Strategy and Operations.

Ivan Antônio Pinheiro is Professor of Public Management and Innovation Management at Universidade Federal do Rio Grande do Sul - UFRGS, Porto Alegre, Brazil. He earned his Ph.D. degree in Business Studies from Universidade Federal do Rio Grande do Sul. He is teaching at Post-Graduate Program in Management in Public Management and Innovation. He is also Lecturer and reviewer of several national journals: RAP, SAR, READ, among others, as well as the Congress and national and international seminars. Ad hoc consultant and researcher at $\mathrm{CNPq}$. 